Natural Hazards and Earth System Sciences, 5, 993-1001, 2005

SRef-ID: 1684-9981/nhess/2005-5-993

European Geosciences Union

(C) 2005 Author(s). This work is licensed

under a Creative Commons License.

\title{
Calibration of numerical models for small debris flows in Yosemite Valley, California, USA
}

\author{
P. Bertolo ${ }^{1}$ and G. F. Wieczorek ${ }^{2}$ \\ ${ }^{1}$ DITAG (Dept of Land, Environment and Geotechnology), Politecnico di Torino, Italy \\ ${ }^{2}$ US Geological Survey, Menlo Park, CA, USA
}

Received: 27 July 2005 - Revised: 1 December 2005 - Accepted: 1 December 2005 - Published: 13 December 2005

Part of Special Issue "Documentation and monitoring of landslides and debris flows for mathematical modelling and design of mitigation measures"

\begin{abstract}
This study compares documented debris flow runout distances with numerical simulations in the Yosemite Valley of California, USA, where about $15 \%$ of historical events of slope instability can be classified as debris flows and debris slides (Wieczorek and Snyder, 2004).

To model debris flows in the Yosemite Valley, we selected six streams with evidence of historical debris flows; three of the debris flow deposits have single channels, and the other three split their pattern in the fan area into two or more channels. From field observations all of the debris flows involved coarse material, with only very small clay content.
\end{abstract}

We applied the one dimensional DAN (Dynamic ANalysis) model (Hungr, 1995) and the two-dimensional FLO2D model (O'Brien et al., 1993) to predict and compare the runout distance and the velocity of the debris flows observed in the study area. As a first step, we calibrated the parameters for the two softwares through the back analysis of three debris- flows channels using a trial-and-error procedure starting with values suggested in the literature. In the second step we applied the selected values to the other channels, in order to evaluate their predictive capabilities.

After parameter calibration using three debris flows we obtained results similar to field observations We also obtained a good agreement between the two models for velocities. Both models are strongly influenced by topography: we used the $30 \mathrm{~m}$ cell size DTM available for the study area, that is probably not accurate enough for a highly detailed analysis, but it can be sufficient for a first screening.

Correspondence to: P. Bertolo

(paola.bertolo@polito.it)

\section{Introduction}

The objective of this study is the calibration of numerical debris flow models to predict the critical motion characteristics of debris flows in Yosemite Valley, California, USA. Debris flows, and also debris avalanches, are extremely destructive, killing hundreds of people and causing million of dollars of property damage throughout the world every year. This is why accurate prediction of runout distances and velocities can reduce these losses by providing a means to delineate hazard areas, to estimate hazard intensity for input into risk studies and to provide parameters for the design of protective measures.

Many landslides with long travel distances are flow-like in character. Some of these landslides, such as debris flows, are saturated and have distributed velocity profiles resembling the flow of a fluid (Hungr, 1995). Other landslides, such as rockfall avalanches, contain stronger material with limited internal deformation and move on thin mobile basal layers where shear strain is concentrated. The multilingual landslide glossary prepared by the UNESCO, in particular the Work Part on World Lanslide Inventory, uses the general kinematic term "Composite Flows" (WP/WLI, 1993) to describe landslides with flow-like of motion.

In the Yosemite Valley of California, USA, about $15 \%$ of historical landslide events can be classified as debris flows and debris slides (Wieczorek and Snyder, 2004). Two people have were killed by debris flows in this area in 1977 (Wieczorek, personal communication, 2005), and several roads and trails have also been damaged since 1851 (Wieczorek and Snyder, 2004). Some debris flows have carried rocky debris far into the valley on moderately gentle slopes to the banks of the Merced River.

To model debris flows in the Yosemite Valley, we selected six streams with evidence of historical debris flows 


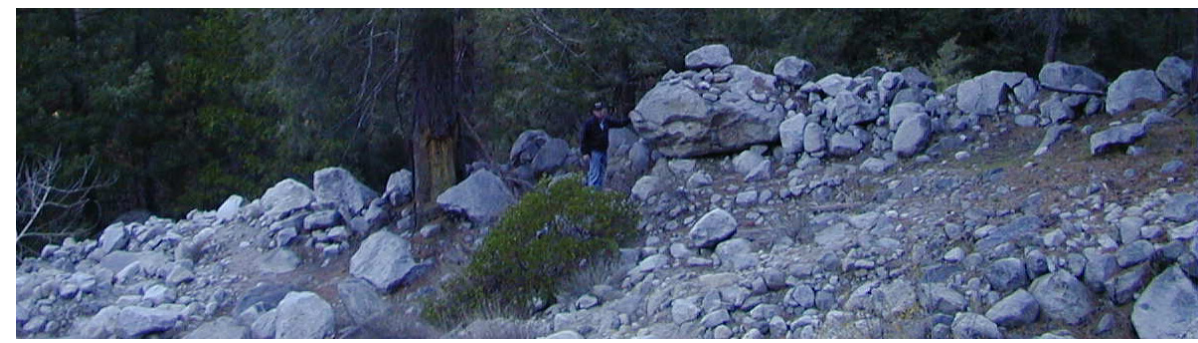

Fig. 1. Lateral levees along Channel 4 (Fig. 4) in Yosemite Valley.

and we applied the one dimensional DAN (Dynamic ANalysis) model (Hungr, 1995) and the two-dimensional FLO2D model (O'Brien et al., 1993) to predict and compare the runout distances and velocities of the debris flows observed in the study area. As a first step, we calibrated the parameters of the two models through the back analysis of three debrisflow channels using a trial-and-error procedure starting with values suggested in the literature. In the second step we applied the selected values to the remaining three channels, in order to evaluate the models predictive capabilities.

\section{Geology in Yosemite}

Yosemite Valley is probably the world's best known example of a glacier-carved canyon. Yosemite Valley waterfalls, rounded domes, massive monoliths and towering cliffs, which have inspired painters, poets and photographers and have fascinated millions of tourists, are the result of alterations made by glaciers.

The geologic history of Yosemite can be started 500 million years ago (Paleozoic), when the Sierra Nevada region was submerged by the sea and sediments were slowly accumulated on the ocean floor. About 200 million years ago (Mesozoic) part of the Pacific plate subducted under the North American plate (Bateman, 1983), causing the Pacific plate to melt into magma. Between 100 to 80 million years ago the magma rose toward the surface and cooled underground into a huge block of granite (American Park Network, 2001), creating the emplacement youngest granite. In the next 50 millions of year, the erosion reduced the ancestral Sierra Nevada to rolling upland with low topographic relief (Huber, 1989) with several streams, including the Merced River.

Starting about 20 million years ago the Sierra Nevada block uplifted, tilting westward (Matthes, 1930), increasing the Merced River's flow so it carved the valley into a canyon and 3 million years ago the main canyon was as much as $1000 \mathrm{~m}$ deep, while the Merced's tributaries cut the land at a slower rate. After that the Ice Age approached, and until 250000 years ago glaciers filled the Yosemite Valley, deepening and carving it into a U-shape. The Valley's sheer walls and flat floor evolved as alpine glaciers moved through the canyon of the Merced River forming hanging valleys from which waterfalls now cascade. The ice carved through weaker sections of granite, plucking and scouring rock but leaving intact harder portions, such as Half Dome, El Captain and Cathedral Rocks (American Park Network, 2001).

When the last glacier melted, about 15000 years ago following Tioga glaciation a terminal moraine dammed the melting water to form the ancient Lake Yosemite. Eventually sediment filled in the lake, forming today's flat valley floor.

Yosemite Valley is well known for its magnificently displayed rock esposure, and all granitic rocks dominate the entire scene. Granite is the most common lithology, although other plutonic rocks, especially granodiorite and tonalite are present. The most prominent geologic units within the debris flow study area are the El Captain Granite and the Sentinel Granodiorite (Calkins, 1985). All the plutonic rocks within Yosemite National Park proper are believed to be of Cretaceous age, with the possible exception of some small bodies of diorite and gabbro that may be somewhat older (Huber, 1989).

\section{Landslides in Yosemite}

Landslides are an important element of landscape development in Yosemite Valley. More than 250 landslides have occurred in historic times and twelve people have been killed and others injuried (Wieczorek and Snyder, 2004). Two people were killed as result of a debris flow in 1977 (Wieczorek, personal communication, 2005).

Most landslides, especially large rock falls and rock avalanches, have initiated in the zone of weathered rock between the level of Tioga glaciation and the unglaciated boundary. Many of the larger debris slides and flows have also initiated in saprolite or colluvium within the zone of weathered rock above the level of Tioga glaciation. At a lower elevations, most of the valley has probably been free of glacial ice since about $15000 \mathrm{yBP}$ (Wieczorek and Jäeger, 1996), and only quite small rock falls and slides have occurred within the jointed granitic rocks below the level of Tioga glaciation.

The abundant debris-flow deposits in Yosemite Valley were first mapped by Matthes (1930), although he described these fans as coarse rock waste produced by torrent action. The more recent map of Wieczorek et al. (1999) identifies 


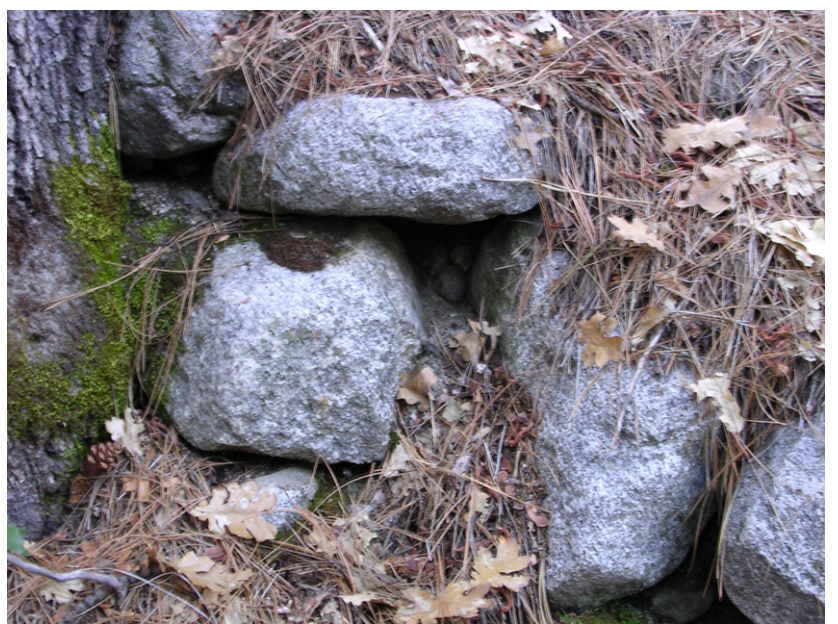

Fig. 2. Typical corse debris-flow deposit.

these deposits as originated by debris flows, and classifies them as prehistoric (before 1852), historic, and recent.

The larger debris-flow fans are found where Eagle, Sentinel, Bridaveil and Indian Creeks enter the Yosemite Valley, at the toe of the mountain front where the channel gradient decreases. All the observed debris-flows channels have a Vshaped or rectangular cross section, and at the side of the channel coarse debris (Fig. 1) forms lateral ridges, that can be several meters high.

On the basis of depositional fabric and clast size, coarse deposits with boulders can be distinguished from fluvial deposits that are grain supported and ofter lack large clasts: in Yosemite Valley there are mostly coarse deposits (Fig. 2), although very fluid debris flow have carried rocky debris far into the valley on moderately gentle slopes (Fig. 3).

\section{Modelling debris flows}

Many relations or flow laws have been proposed in literature to describe the flow and the runout distance of debris flows. The application of these formulations requires knowledge of the suitability to investigate torrents. Moreover each model has to be systematically calibrated if it is to be used for predictive purpose and, if possible, it has to be tested against a large sample of events, because different model configurations and parameter ranges will need to be used for different situations. Furthermore it is to remember that the rheological behaviour of a flow can change even for events occurring in the same torrent, thus the study is focused on the definition of a reliable range of parameters capable of cover the major number of events, althought a different event may always occur.

In this study attention was focused on debris flows within a small area, with homogeneous characteristics in term of geology, morphology and climate, so the goal was to find, if possible, a range of parameters for a geographically localized set of events. Simulation results using different single-phase,

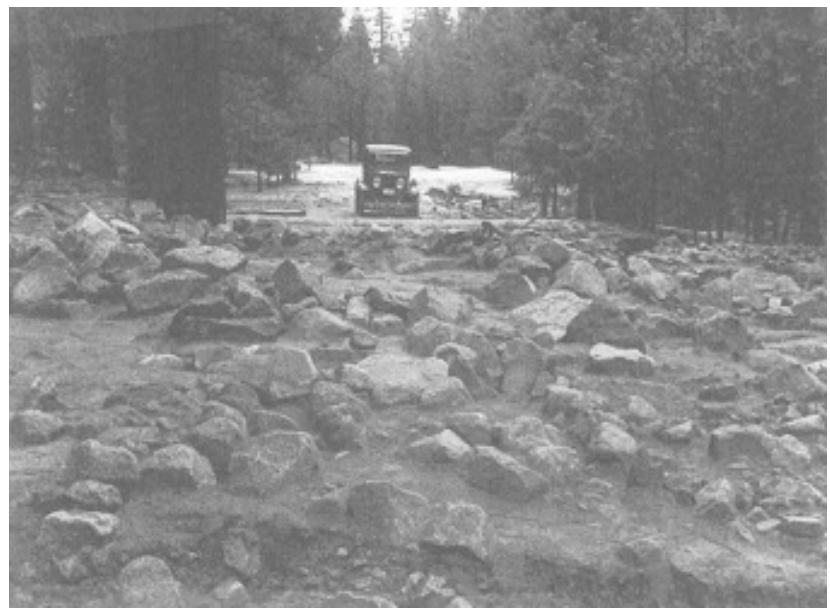

Fig. 3. Ash Can debris flow across road during 1937 in Yosemite Valley.

non-Newtonian flow laws implemented in two different computational models were compared. At present, physicallybased, realistic two-phase flow laws, with the description of the state and properties of the liquid and the solid phase, are also available (Iverson and Denlinger, 2001), but singlephase relations are, at present, more commonly used, and can provide more simple and immediate results, for example following the idea of an "equivalent fluid" proposed by Hungr (1995).

We worked with two, well known, models: the Dynamic ANalysis (DAN) model, developed by Hungr (1995) for the runout analysis of rapid flow slides, debris flows and debris avalanches, and the FLO-2D model, originally created in 1988 to conduct a Federal Emergency Management Agency (FEMA) flood insurance study of an urbanized alluvial fan in Colorado (FLO-2D Users Manual, 2003). Both software models are only briefly illustrated here, because they have been described in the other papers cited above.

DAN is a one-dimensional numerical model of unsteady flow, developed exclusively for the analysis of rapid landslides. The purpose of DAN is to serve as a versatile tool for modeling post failure motion. DAN is a continuum model based on a Lagrangian solution of the equations of motion and allows the selection of a variety of material rheologies, which can vary along the slide path or within the slide mass (Hungr, 1995). The motion of flow slides and debris flows is very complex and the deformation behaviour can take place by dislocation along discrete failure surfaces, like in solid materials, or continuosly in what is called flow. Standard concepts of fluid mechanics such as hydrostatic internal stress and homogeneity are often not applicable, moreover it is very difficult to find a unique constitutive relationship applicable to all parts of the flow. DAN follows the simplified concept of "equivalent fluid" presented by Hungr (1995), where the moving mass, which may in reality be heterogeneous and complex, is replaced by an equivalent fluid whose bulk properties will approximate the behaviour, in terms of 


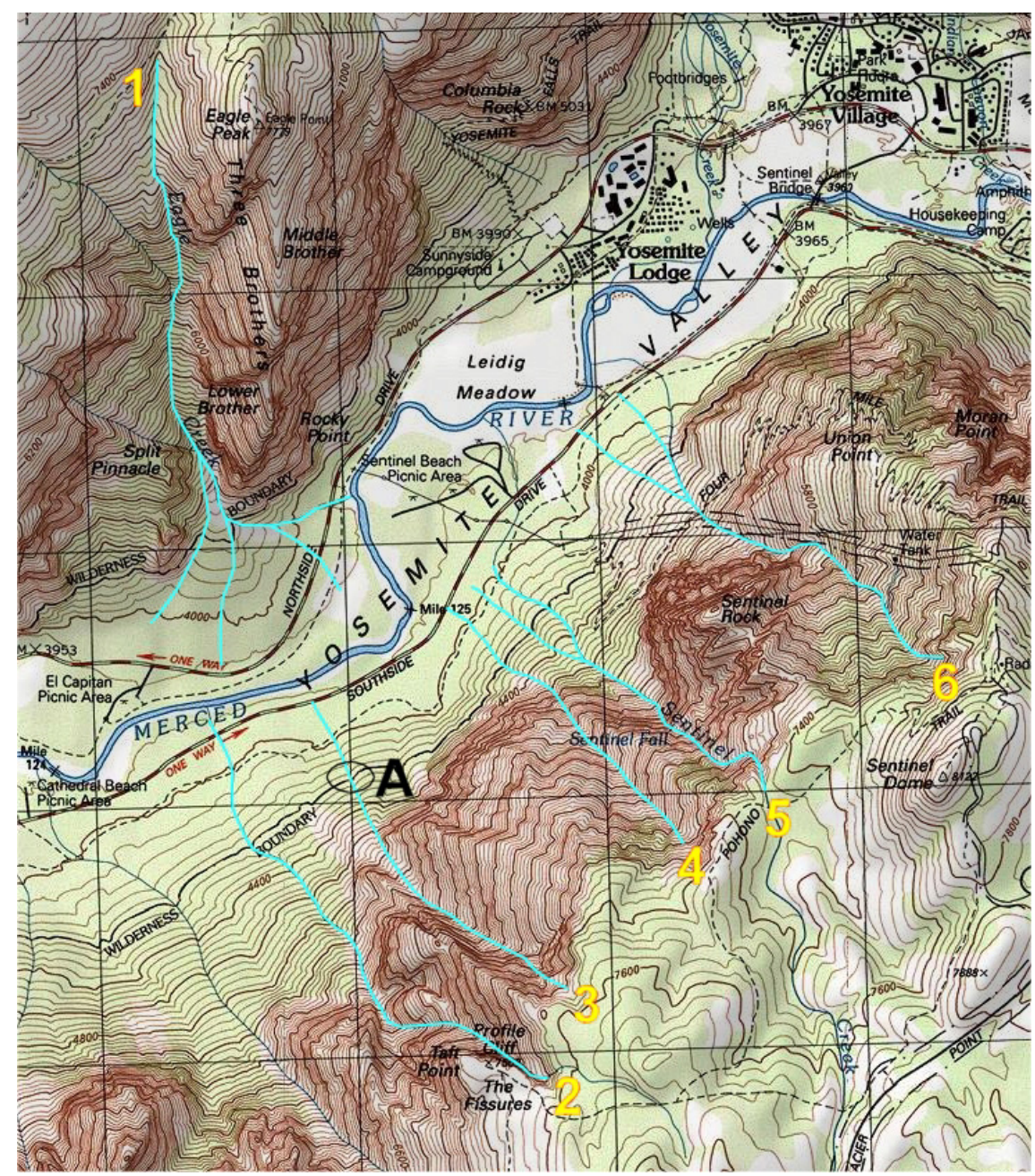

Fig. 4. Map of the studied debris flow areas with numbers identifying individual six debris flow channels.

external shape and mean velocity depending on the selected rheology of the flow.

The FLO-2D is a simple volume conservation model that distributes a flood hydrograph over a system of square grid elements (tiles) (FLO-2D Users Manual, 2003). It implements the Diffusive Hydrodynamic Model (DHM) created by Hromadka and Yen (1987), which is a simple numerical approach with a finite difference scheme that permits modification of the grid element attributes. FLO-2D allows the user to delineate flood hazards and designing flood mitigation. Details can be added to the simulation by turning on or off switches for various components such as streets, sediment transport, culverts and many others. Channel flow is onedimensional, with the channel geometry represented either by natural, rectangular or trapezoidal cross sections, whereas overland flow is modeled two-dimensionally and channel overbank flow is computed when the channel capacity is exceeded (FLO-2D Users Manual, 2003). When the flow overtops the channel, it will disperse to other overland grid elements based on topography, roughness and obstructions. FLO-2D routes hyperconcentrated sediment flows (mud and debris flows) as a fluid continuum by predicting viscous fluid motion. A quadratic rheologic model for predicting viscous and yield stresses as function of sediment concentration is employed and sediment volumes are tracked through the system. As sediment concentration changes for a given grid element, dilution effects, flow cessation and the remobilization of deposits are simulated (FLO-2D Users Manual, 2003).

\section{Procedure}

In this study the calibration of the models was based on a trial-and-error selection of rheological models and parameters, and the adjustment of the input parameters which define the flow resistance.

In order to better calibrate the numerical models, especially to evaluate their predictive capacity, we divided our sample of six basins in two parts: we carried out the calibration through the back analysis of three debris flows (channels 1, 2 and 4, Fig. 4), and then we applied the parameters that provided the best fit with field observations to the other three 
channels, to evaluate the parameter reliability for predictive purposes.

\subsection{DAN model}

First we applied the DAN software: once a rehology was selected the parameters were adjusted accordingly until an accurate fit of the observed runout distance was obtained.

The frictional model

$\tau=\gamma \cdot H \cdot\left(\cos \alpha+\frac{a_{c}}{g}\right) \cdot\left(1-r_{u}\right) \cdot \tan \varphi$

(where $\tau$ is the basal flow resistence, $\gamma$ is bulk unit weight, $H$ is the flow depth, $\alpha$ is the channel slope, $a_{c}$ is the centrifugal acceleration, $g$ is the gravity acceleration, $r_{u}$ is the pore-pressure coefficient and $\varphi$ is the friction angle) is a starting point for the analysed area because Yosemite valley is characterized by coarse debris flow events, with negligible clay contents, as we could see from field observations. Although the frictional model has provided excellent results for many rock avalanches (Hungr and Evans, 1996), flow-slides in coarse mine waste (Hungr at al., 2002) and debris avalanches, in our back analysis it turned out that the model provided a consistent overestimation of velocities (over $50 \mathrm{~m} / \mathrm{s}$ ) probably because of the small magnitude (less than $1000 \mathrm{~m}^{3}$ of material) of the analysed events. The same trend is shown also in an article of Ayotte and Hungr (2000).

As a second rheology we adopted the two-parameter model of Voellmy (1955)

$\tau=\gamma \cdot H \cdot\left(\cos \alpha+\frac{a_{c}}{g}\right) \cdot\left(1-r_{u}\right) \cdot \tan \varphi+\gamma \cdot \frac{v^{2}}{\xi}$

(where $v$ is the velocity and $\xi$ is a turbolence coefficient; the other terms are similar as in Eq. 1) which adds a turbulence parameter $\xi$, intended to cover all velocity-dependent factors, to the frictional model: this empirical model was built for snow avalanches by combining Coulomb frictional and Chezy formulas. Koerner (1976) showed that the model offers a good simulation of velocities for rock avalanches, and Rickenmann and Koch (1997), succesfully applied the model to debris flows. This rheology is simple to calibrate, because it only requires the estimation of two empirical parameters ( $\varphi$ and $\xi$ ).

Additional simulations were made using the Bingham constitutive equation:

$\tau=\tau_{y}+\mu_{B} \frac{d v}{d y}$

(where $\tau_{y}$ is the yield stress and $\mu_{B}$ is the Bingham viscosity). The Bingham rheology ignores the inertial stress and assumes the flow as viscous, althought it is known that even mudflows with concentrations up to $40 \%$ in volume can be turbulent (O'Brien, 1986).

We carried out the analysis with three different combinations:
1. Frictional model for the source material, with a bulk friction angle $\phi_{B}\left(\tan \phi_{B}=\left(1-r_{u}\right) \cdot \tan \varphi\right)$ between $25^{\circ}$ and $26^{\circ}$, and the Voellmy two-parameter model for the variation of material properties along the flow path, with a friction angle $\varphi$ ranging between $5.7^{\circ}$ and $11.5^{\circ}$ (friction coefficient $0.1-0.12$ ) and a turbulence coefficient $\xi$ of $500-600 \mathrm{~m} / \mathrm{s}^{2}$;

2. Voellmy two-parameter model for the whole simulation, with the same parameters reported above;

3. Bingham constitutive equation for the whole simulation with values of yield stress $\tau_{y}$ ranging between 0.15 and $0.30 \mathrm{kPa}$, and a Bingham viscosity $\mu_{B}$ between $0.8 \mathrm{kPa}$ and $1.0 \mathrm{kPa}$.

The DAN model can also take account the amount of material entrained by the flow along the path thereby increasing the final volume deposited. We tested this option, but it didn't seem to influence the runout distance of the study cases, probably because all the events were relatively small debris flows, with a volume of involved solid material less than $1000 \mathrm{~m}^{3}$.

Table 1 lists the rheological models and the corresponding parameters, and presents the final results of the calibration and the simulation for each case. Applying parameters chosen among those obtained from the calibration of channel 1, 2 and 4 , according to their capability to best simulate the field data, at the three test channels, we obtained good results in terms of runout distance with all the three combinations of rheology. The main difference is in the position of the tail of the deposited material: with the Voellmy rheology all the material deposits on the fan, whereas with the combination of Frictional model for the source material and the Voellmy two-parameter model for the material along the flow path in two of the calibration streams part of the removed material stops near the source area and there is deposition all along the channel, although there are only few millimeters of deposit due to the small magnitude of the events. With the Bingham rheology, the source volume deposits a very thin layer of material along the whole channel, from the top of the channel to the bottom of the fan.

\section{$5.2 \quad$ FLO-2D model}

The FLO-2D software models the shear stress in hyperconcentrated sediment flows, including those described as debris flows, mudflows and mud floods, as a summation of five shear stress components: the cohesive yield stress, the MohrCoulomb shear, the viscous shear stress, the turbulent shear stress and the dispersive shear stress. All these components can be written in terms of shear rates giving a quadratic rheological model function of sediment concentration, that adds a turbulent and dispersive term to the Bingham equation (FLO2D Users Manual, 2003). A discussion of these stresses and their role in hyperconcentrated sediment flows can be found in Julien and O'Brien (1997). 
Table 1. Rheological models and corresponding parameters. Final results of the calibration (channels 1,3 and 4 ) and the simulation (Test channels 2,5, and 6).

\begin{tabular}{|c|c|c|c|c|c|c|c|c|c|}
\hline \multirow{3}{*}{$\begin{array}{c}\text { Channel } \\
1 \\
\text { Calibration }\end{array}$} & \multirow{3}{*}{$\begin{array}{c}\text { Split } \\
\text { Yes }\end{array}$} & \multicolumn{4}{|c|}{ FRICTIONAL (source) + VOELLMY (channel) } & \multicolumn{2}{|c|}{ VOELLMY } & \multicolumn{2}{|c|}{ BINGHAM } \\
\hline & & $\varphi\left(^{\circ}\right)$ & 36 & Frict coeff & 0.12 & Frict coeff & 0.12 & $\tau_{y}(\mathrm{kPa})$ & 0.24 \\
\hline & & $r_{u}$ & 0.34 & $\xi\left(\mathrm{m} / \mathrm{s}^{2}\right)$ & 500 & $\xi\left(\mathrm{m} / \mathrm{s}^{2}\right)$ & 500 & $\mu_{B}(\mathrm{kPa})$ & 1 \\
\hline Measured front & & $\gamma\left(\mathrm{kN} / \mathrm{m}^{3}\right)$ & 26 & $\gamma\left(\mathrm{kN} / \mathrm{m}^{3}\right)$ & 22 & $\gamma\left(\mathrm{kN} / \mathrm{m}^{3}\right)$ & 22 & $\gamma\left(\mathrm{kN} / \mathrm{m}^{3}\right)$ & 22 \\
\hline runout dista & $1275 \mathrm{~m}$ & Simulation $(m)$ & & Rear: 41 & Front: 1274 & Rear: 1188 & Front: 1295 & Rear: 81 & Front: 1275 \\
\hline 2 & & $\varphi\left(^{\circ}\right)$ & 36 & Frict coeff & 0.1 & Frict coeff & 0.1 & $\tau_{y}(\mathrm{kPa})$ & 0.15 \\
\hline Calibration & No & $r_{u}$ & 0.34 & $\xi(\mathrm{m}$ & 600 & $\xi\left(\mathrm{m} / \mathrm{s}^{2}\right)$ & 600 & $\mu_{B}(\mathrm{kPa})$ & 0.8 \\
\hline Measured & & $\gamma\left(\mathrm{kN} / \mathrm{m}^{3}\right)$ & 26 & $\gamma\left(\mathrm{kN} / \mathrm{m}^{3}\right)$ & 22 & $\gamma\left(\mathrm{kN} / \mathrm{m}^{3}\right)$ & 22 & $\gamma\left(\mathrm{kN} / \mathrm{m}^{3}\right)$ & 22 \\
\hline runo & $1480 \mathrm{~m}$ & Simulation $(m)$ & & Rear: 1230 & Front: 1459 & Rear: 1230 & Front: 1459 & Rear:39 & Front: 1273 \\
\hline 3 & & $\varphi\left(^{\circ}\right)$ & 36 & Frict coeff & 0.1 & Frict coeff & 0.1 & $\tau_{y}(\mathrm{kPa})$ & 0.2 \\
\hline Test & no & $r_{u}$ & 0.34 & $\xi\left(\mathrm{m} / \mathrm{s}^{2}\right)$ & 600 & $\xi\left(\mathrm{m} / \mathrm{s}^{2}\right)$ & 600 & & 0.8 \\
\hline $\mathrm{M}$ & & $\gamma\left(\mathrm{kN} / \mathrm{m}^{3}\right)$ & 26 & $\gamma\left(\mathrm{kN} / \mathrm{m}^{3}\right)$ & 22 & $\gamma\left(\mathrm{kN} / \mathrm{m}^{3}\right)$ & 22 & $\gamma\left(\mathrm{kN} / \mathrm{m}^{3}\right)$ & 22 \\
\hline runot & $814 \mathrm{~m}$ & Simulation $(\mathrm{m})$ & & Rear:0 & Front: 781 & Rear: 728 & Front: 781 & Rear: 4 & ont:779 \\
\hline 4 & & $\varphi\left(^{\circ}\right)$ & 36 & Frict coeff & 0.12 & Frict coeff & 0.12 & $\tau_{y}(\mathrm{kPa})$ & 0.3 \\
\hline Calibr: & $\mathrm{nc}$ & $r_{u}$ & 0.34 & $\xi(1$ & 500 & $\xi\left(\mathrm{m} / \mathrm{s}^{2}\right)$ & 500 & $\mu_{B}(\mathrm{l}$ & 1 \\
\hline Meas & & $\gamma\left(\mathrm{kN} / \mathrm{m}^{3}\right)$ & 26 & $\gamma\left(\mathrm{kN} / \mathrm{m}^{3}\right)$ & 22 & $\gamma\left(\mathrm{kN} / \mathrm{m}^{3}\right)$ & 22 & $\gamma\left(\mathrm{kN} / \mathrm{m}^{3}\right)$ & 22 \\
\hline runout dist & $652 \mathrm{~m}$ & Simulation $(\mathrm{m})$ & & Rear:569 & Front: 643 & Rear:569 & Front: 644 & Rear: 8.5 & Front: 663 \\
\hline 5 & & $\varphi\left(^{\circ}\right)$ & 36 & Frict coeff & 0.12 & Frict coeff & 0.12 & $\tau_{y}(\mathrm{kPa})$ & 0.24 \\
\hline Test & yes & $r_{u}$ & 0.34 & $\xi\left(\mathrm{m} / \mathrm{s}^{2}\right)$ & 500 & $\xi\left(\mathrm{m} / \mathrm{s}^{2}\right)$ & 500 & $\mu_{B}(\mathrm{kPa})$ & 1 \\
\hline Mea & & $\gamma\left(\mathrm{kN} / \mathrm{m}^{3}\right)$ & 26 & $\gamma\left(\mathrm{kN} / \mathrm{m}^{3}\right)$ & 22 & $\gamma\left(\mathrm{kN} / \mathrm{m}^{3}\right)$ & 22 & $\gamma\left(\mathrm{kN} / \mathrm{m}^{3}\right)$ & 22 \\
\hline run & $4 \mathrm{~m}$ & Simu & & Rear: 1065 & Front:1146 & Rear: 1064 & Front: 1146 & Rear: 38 & Front:1143 \\
\hline 6 & & $\varphi\left({ }^{\circ}\right)$ & 36 & Frict coeff & 0.1 & Frict coeff & 0.1 & $\tau_{y}(\mathrm{kPa})$ & 0.24 \\
\hline Test & y & $r_{u}$ & 0.34 & $\xi\left(\mathrm{m} / \mathrm{s}^{2}\right)$ & 600 & $\xi\left(\mathrm{m} / \mathrm{s}^{2}\right)$ & 600 & $\mu_{B}(\mathrm{kPa})$ & 0.8 \\
\hline Measured $\mathrm{f}$ & & $\gamma\left(\mathrm{kN} / \mathrm{m}^{3}\right)$ & 26 & $\gamma\left(\mathrm{kN} / \mathrm{m}^{3}\right)$ & 22 & $\gamma\left(\mathrm{kN} / \mathrm{m}^{3}\right)$ & 22 & $\gamma\left(\mathrm{kN} / \mathrm{m}^{3}\right)$ & 22 \\
\hline runout dista & $812 \mathrm{~m}$ & Simulation $(m)$ & & Rear:701 & Front: 786 & Rear:700 & Front: 786 & Rear: 15 & Front: 827 \\
\hline
\end{tabular}

Table 2. Basin characteristics and water discharge evaluation.

\begin{tabular}{lccccc}
\hline & $\begin{array}{c}\text { Channel } \\
\#\end{array}$ & $\begin{array}{c}\text { Catchment } \\
\text { area }\left(\mathrm{km}^{2}\right)\end{array}$ & $\begin{array}{c}\text { Channel } \\
\text { steepness }\left(^{\circ}\right)\end{array}$ & $\begin{array}{c}\text { Channel } \\
\text { width }(\mathrm{m})\end{array}$ & $\begin{array}{c}\text { Maximum water } \\
\text { discharge }\left(\mathrm{m}^{3} / \mathrm{s}\right)\end{array}$ \\
\hline E. R. Hedman and & 1 & 3.5 & 30 & 10.7 & 180 \\
W. R. Osterkamp & 2 & 1 & 30 & 4.6 & 55 \\
equation: & 3 & 0.7 & 35 & 4.0 & 45 \\
$\mathrm{Q}_{50}=44 \cdot \mathrm{W}_{A C}^{1.40}$ & 4 & 0.8 & 35 & 4.6 & 55 \\
$\mathrm{~W}_{A C}:$ active channel width (ft) & 5 & 0.35 & 40 & 6.0 & 83 \\
$\mathrm{Q}_{50}:$ discharge $(\mathrm{cft} / \mathrm{s})$ & 6 & 1.2 & 38 & 6.0 & 83 \\
\hline
\end{tabular}

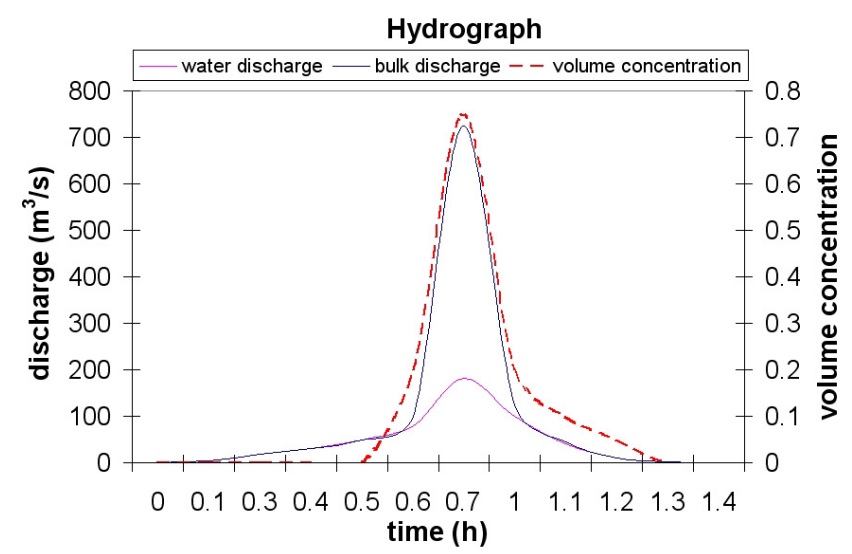

Fig. 5. Example of input hydrograph.

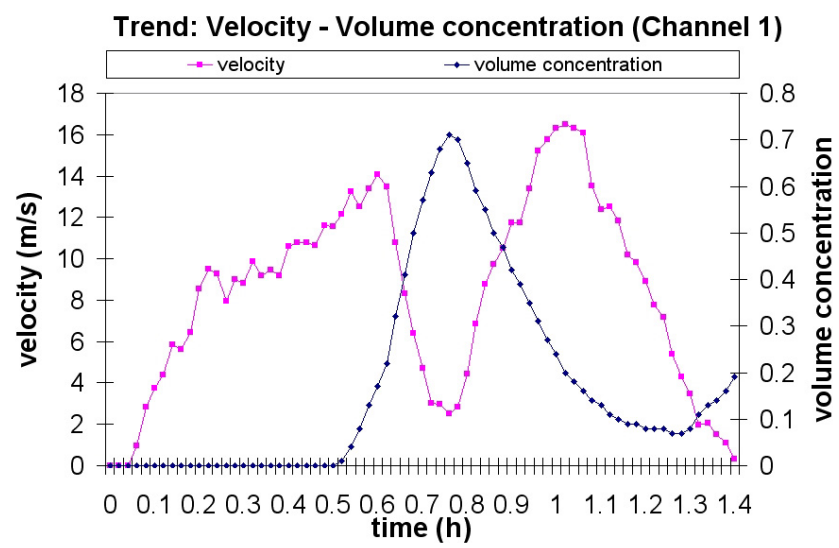

Fig. 6. Plot of computed velocity and concentration versus time in a section of Channel 1. 
Channel 1 - Velocity predictions

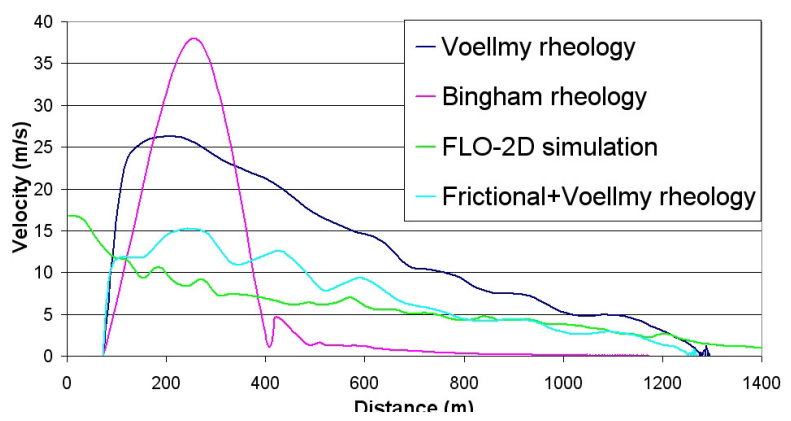

Channel 3 - Velocity predictions

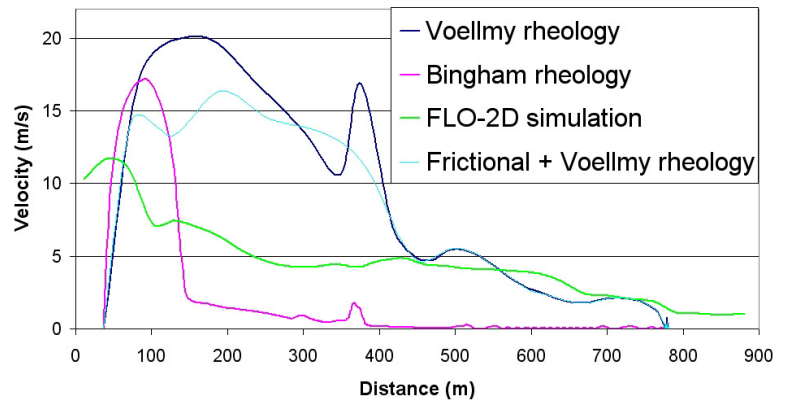

Fig. 7. Velocity predictions for two of the analysed channels.
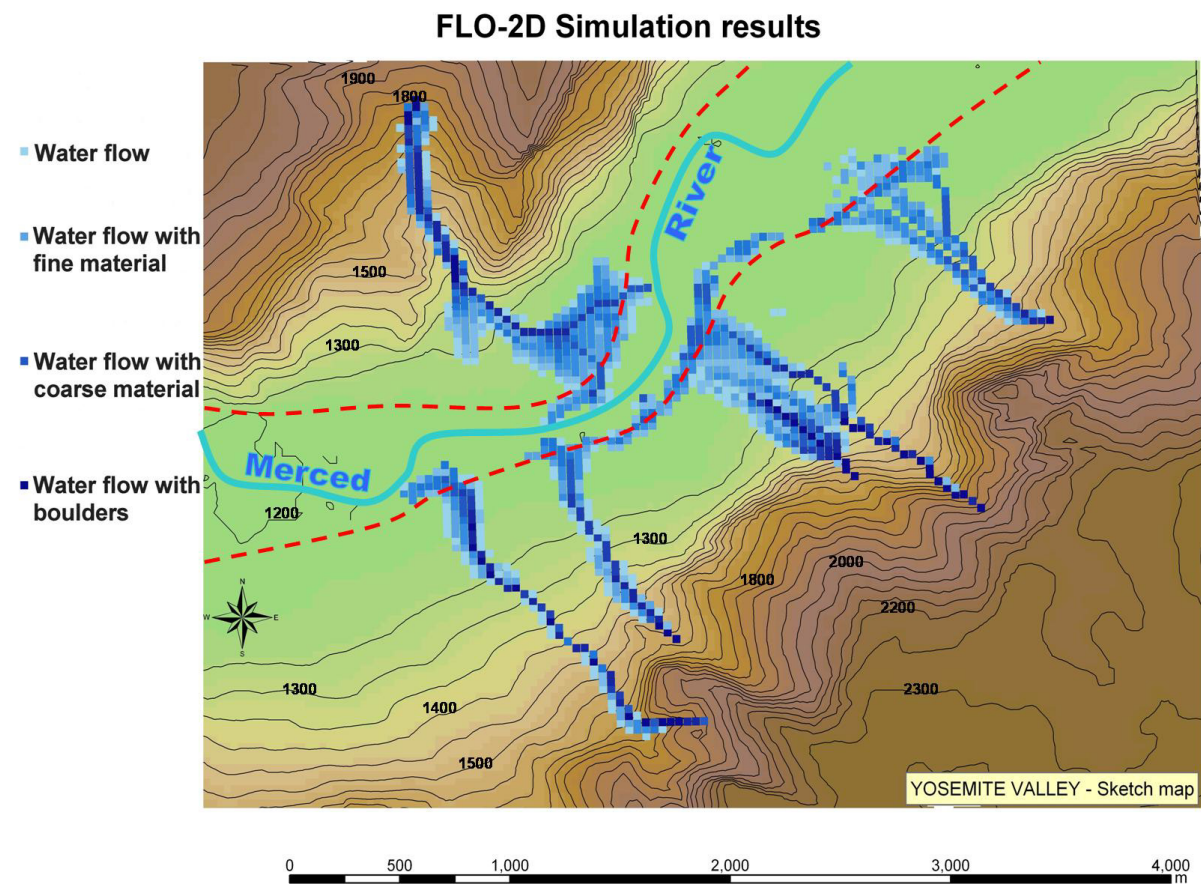

Fig. 8. FLO-2D simulation results for the study area.

There are two important steps to start a simulation with FLO-2D: obtaining the topographic data base and developing the flood hydrology. For the first step, we obtained the $30 \mathrm{~m}$ DTM from the National Elevation Dataset, produced by the USGS, and we prepared a $30 \mathrm{~m}$ square grid system.

The second step arises from the fact that each flood simulation requires an inflow flood hydrograph or a rain storm. There were no rain or discharge gauges in any of the basins to evaluate the rain that triggered past events, therefore we evaluated the maximum discharge for each channel with an empirical relation that relates the width of the active channel with the maximum discharge for a given recurrence interval (Hedman and Osterkamp, 1982) (Table 2).

For predicting viscous and yield stresses, the program requires the coefficient and the exponent of the relations

$\mu=\alpha \cdot e^{\beta \cdot C_{v}} \tau_{y}=\alpha \cdot e^{\beta \cdot C_{v}}$ where $C_{v}$ is the volume concentration. For the viscosity $\mu$, we used a coefficient $\alpha=2.72$ and an exponent $\beta=11$, and for the yield stress $\tau_{y}$ we used a coefficient $\alpha=0.054$ and an exponent $\beta=14.5$, starting from literature values (FLO-2D Users Manual, 2003), as the best values from the back analysis which results in the same values of Bingham parameters for the maximum sediment concentration in the hydrograph. In the input hydrograph the maximum sediment concentration by volume during the simulation was up to $75 \%$ (Fig. 5). The Manning's coefficient $n$-values, based on field observations, were 0.05 to 0.2 for the floodplains and 0.04 to 0.75 for the channels.

FLO-2D returns, for each cell, volume concentration, velocity (Fig. 6), discharge and stage (depth) during all times in the simulation: the velocity changes with the volume concentration, and we selected as the debris flow front velocity the one corresponding with a concentration of about $60 \%$ of 


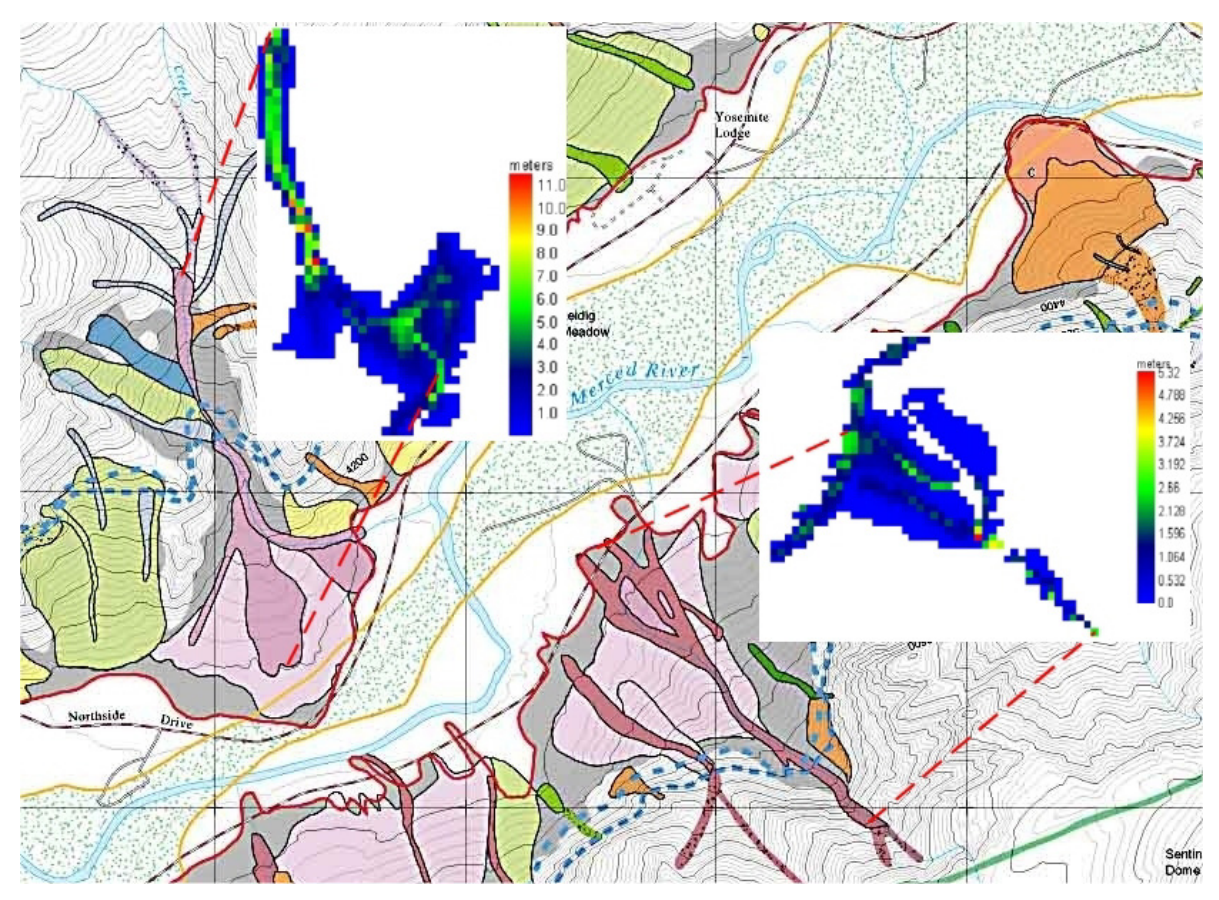

Fig. 9. Comparison of FLO-2D predictions and field mapping (Wieczorek et al., 1999) of debris flow spreading.

the maximum, which corresponds with a sediment volume concentration of 40 to $45 \%$. That velocity was chosen at the time when the flow depth started to increase quickly.

\subsection{Comparison of model results}

The comparison between the velocity obtained from the two models (Fig. 7) shows a good agreement for all the selected rheologies, except for the Bingham model, where the low velocities cause a very long duration of the transport and the depositional stage, which seems not to be realistic for these coarse debris-flow events.

To have an indication of the velocity of the flow in a distal sector of the fan of Channel 3 (Point A, Fig. 4), we evaluated the velocity $(v)$ in a curve (Costa, 1984) measuring the superelevation angle of the flow surface between the inside and the outside of the bend $\left(\delta \approx 11^{\circ}\right)$ and the radius of curvature of the channel $\left(r_{c} \approx 12 \mathrm{~m}\right)$. Using the formula $v=\sqrt{ }\left(r_{c} \cdot g \cdot \tan \delta\right)$, we estimated the debris flow velocity in that point $v=4.8 \mathrm{~m} / \mathrm{s}$. The simulated values of the velocity in that point were: $4.65 \mathrm{~m} / \mathrm{s}$ with the Voellmy rheology (the same as with the Frictional + Voellmy rheology) and $0.61 \mathrm{~m} / \mathrm{s}$ with the Bingham rheology using the DAN program, and $4.5 \mathrm{~m} / \mathrm{s}$ using the FLO-2D program.

\section{Conclusions}

After parameter calibration from the back analysis of three debris-flow events in Yosemite Valley, we obtained accurate runout distances for the three test channels from the DAN model. The FLO-2D model creates an accurate representation of the material spreading on the fan and depicted where the channels split (Fig. 8). Both of these results were in agreement with field observations (Fig. 9). We also obtained a good agreement between the two models for velocities, except for the Bingham rheology in the DAN software, with maximum values of $20 \mathrm{~m} / \mathrm{s}$ in the upper portion of the channels where the slope is about $30^{\circ}$. Values ranging from 3 to $7 \mathrm{~m} / \mathrm{s}$ were simulated near the heads of the fans.

Both models are strongly influenced by topography: DAN uses a 1-D stream profile which we obtained from the DTM, and FLO-2D uses a 2-D DTM. We used the $30 \mathrm{~m}$ cell size DTM available for the study area, which is probably not accurate enough for a highly detailed analysis, especially for FLO-2D where the spatial and temporal resolution is closely dependent on the size of the grid elements (Aleotti and Polloni, 2003). The $30 \mathrm{~m}$ DTM can nevertheless be sufficient for a first screening and a reasonable reproduction and prediction of events.

Although the calibrated values of the rheological parameters used in the models differ from one case to another, the simulated order of magnitude effects of these events can be useful to predict future events in this area in order to produce hazard and risk mapping. These estimated parameters can also give a good range to predict debris-flow behaviour in other areas with geology, morphology and climate similar to Yosemite Valley.

Edited by: L. Marchi

Reviewed by: three referees 


\section{References}

Aleotti, P. and Polloni, G.: Two-dimensional model of the 1998 Sarno debris flows (Italy): preliminary results, Debris-Flows Hazards Mitigation: Mechanics, Prediction, and Assessment, edited by: Rickenmann, D. and Chen, C.-L., Millpress, Rotterdam, 553-563, 2003.

American Park Network: Yosemite Geology, http://www. americanparknetwork.com/parkinfo/yo/geology/, 2001.

Ayotte, D. and Hungr, O.: Calibration of a runout prediction model for debris-flows and avalanches, Debris-Floe Hazards Mitigation: Mechanics, Prediction, and Assessment, edited by: Wieczorek, G. F. and Naeser, N. D., Balkema, Rotterdam, 505-514, 2000.

Bateman, P. C.: A summary of critical relations in the central part of the Sierra Nevada batholith, California, USA, in: Circum-Pacific plutonic terranes, edited by: Roddick, J. A., Geological Society of America Memoir, 159, 241-254, 1983.

Calkins, F. C.: Bedrock geologic map of Yosemite Valley.Yosemite National Park, California, with accompanying pamphlet by: Huber, N. K. and Roller, J. A., Bedrock geology of the Yosemite Valley area Yosemite National Park, California, US Geological Survey Miscellaneous Investigations Series Map I-1639, scale 1:24 000, 1985.

Costa, J. E.: Physical geomorphology of debris flows, in: Developments and Applications of Geomorphology, edited by: Costa, J. E., and Fleisher, P. J., Springer-Verlag, New York, 268-317, 1984.

FLO-2D: Users manual, Version 2003.06, Nutrioso, Arizona, USA, 2003.

Hedman, E. R. and Osterkamp, W. R. Streamflow Characteristics Related to Channel Geometry of Streams in Western United States, US Geological Survey Water-Supply Paper 2193, 15-16, 1982.

Hromadka, T. V. and Yen, C. C.: Diffusive hydrodynamic model, US Geological Survey, Water Resources Investigations Report 87-4137, Denver Federal Center, Colorado, 1987.

Huber, N. K.: The Geologic Story of Yosemite National Park. Yosemite Association, Yosemite National Park, California, 1989.

Hungr, O.: A model for the runout analysis of rapid flow slide, debris flow, and avalanches, Canadian Geotechnical Journal, 32, 610-623, 1995.

Hungr, O. and Evans, S. G.: Rock avalanche runout prediction using a dynamic model, Proc. 7th Int. Symp. Landslides, Trondheim, Norway, 1, 233-238, 1996.

Hungr, O., Dawson, R., Kent, A., Campbell, D., and Morgenstern, N. R.: Rapid flow slides of coal mine waste in British Columbia, Canada, in: Catastrophic landslides: Effects, occurrence and mechanisms: Boulder, Colorado, edited by: Evans, S. G. and DeGraff, J. V., Geological Society of America Reviews in Engineering Geology, 15, 191-208, 2002.
Iverson, R. M. and Denlinger, R. P.: Flow of variably fluidized granular masses across three-dimension terrain, 1. Coulomb mixture theory, J. Geophys. Res., 106 (B1), 537-552, 2001.

Johnson, A. M.: Physical processes in geology, San Francisco, Freeman, Cooper \& Company, 577 pp, 1970.

Julien, P. Y. and O'Brien, J. S.: On the importance of mud and debris flow rheology in structural design, in: Debris-Flow Hazards Mitigation: Mechanics, prediction, and Assessment, edited by: Chen, C.-1., ASCE, New York, N.Y., 350-359, 1997.

Koerner, H. J.: Reichweite und Geschwindigkeit von Bergstürzen und Fleis-Schneelawinen, Rock Mechanics, 8, 225-256, 1976.

Matthes, F. E.: Geologic history of the Yosemite Valley, US Geological Survey Professional Paper 160, 137 p., 1930.

O'Brien, J. S.: Physical processes, rheology and modeling of mudflows. Doctoral dissertation, Colorado State University, Fort Collins, Colorado, in: FLO-2D, 2003, Users manual, Version 2003.06. Nutrioso, Arizona, 1986.

O'Brien, J. S., Julien, P. Y., and Fullerton, W. T.: Two-dimensional water flood and mudflow simulation, Journal of Hydraulic Engineering, 119, 244-259, 1993.

Varnes, D. J.: Slope movement types and processes, in: Landslides analysis and control: Washington, D.C., edited by: Schuster, R. L. and Krizek, R. J., Transportation Research Board, National Academy of Science, Special Report 176, 12-33, 1978.

Rickenmann, D. and Koch, T.: Comparison of debris flow modelling approaches, in: Proceedings of the First International Conference on Debris-Flow Hazards Mitigation: Mechanics, Prediction, and Assessment, edited by: Chen, C.-1., New York, ASCE, 576-585, 1997.

Voellmy, A.: Über die Zerstörungskraft von Lawinen, Schweizerische Bauzeitung, 73, 212-285, 1955.

Wieczorek, G. F. and Jäeger, S.: Triggering mechanism and depositional rates of postglacial slope-movement processes in the Yosemite Valley, California, Geomorphology, 15, 17-31, 1996.

Wieczorek, G. F., Morrissey, M. M., Iovine, G., and Godt, J.: Rock-fall potential in the Yosemite Valley, California, US Geological Survey Open-File Report 99-578, 1 plate, scale 1:12000, 7 p., http://greenwood.cr.usgs.gov/pub/ open-file-reports/ofr-99-0578/, 1999.

Wieczorek, G. F. and Snyder, J. B.: Historical Rock Falls in Yosemite National Park, California, US Geological Survey Open File Report 03-491, 2004.

WP/WLI (International Geotechnical Societies' UNESCO Working Party on World Landslide Inventory): Multilingual landslide glossary, BiTech, Richmond, B.C., 1993. 